\title{
Communicative Tasks in a Beginner Coursebook: An Evaluation at the University of Transport and Communications
}

\author{
Nguyen Kim Vu Bao ${ }^{1 *}$ \\ ${ }^{1}$ University of Transport and Communications, No.3 Cau Giay Street, Lang Thuong Ward, Dong Da District, Hanoi, \\ Vietnam
}

\section{*Corresponding Author}

Nguyen Kim Vu Bao

\section{Article History}

Received: 07.03.2021

Accepted: 26.03.2021

Published: 01.04.2021

\begin{abstract}
This paper reports the findings of an evaluative study on the communicative tasks of a beginner-level coursebook recently adopted at the University of Transport and Communications (UTC). The communicative tasks of a unit of the coursebook under evaluation were first described under Littlejohn's (1998) framework. Data were then collected from a convenient sample of 62 students using a student evaluative questionnaire, which asked the participants to evaluate the communicative tasks of the unit. Descriptions of the communicative tasks and analyses of the questionnaire data revealed that the coursebook was generally suitable for the target learners. The communicative tasks were particularly useful for teaching vocabulary and reading skills. However, the grammar and speaking tasks did not seem to meet the participants' expectation of the material. Regarding pronunciation, the students appeared to need further assistance and encouragement from the teacher.
\end{abstract}

Keywords: Coursebook evaluation, communicative task, beginner-level, UTC.

\section{INTRODUCTION}

English has been used in Vietnam for about half a century, developed in the 1990s, and has become a compulsory foreign language in Vietnamese education. In particular, from the 2010-2011 school year, English has also been piloted in grade 3, showing that foreign languages in general and English, in particular, are increasingly playing an important role. However, because the teaching process is outdated in terms of methods, especially the system of textbooks, textbooks, and reference books is limited, so the effectiveness of English teaching and learning in our country is not high.

The quality education process should have three factors: teachers, learning materials (textbooks, reference books, etc.), teaching, and learning conditions. A set of books for modern teaching and learning needs to come from the characteristics of different subjects. So, materials are a crucial part of a successful language teaching program. In the past few decades, the realm of English language teaching (ELT) has seen a dramatic change of approaches and methodology, from a teacher-centered, grammar-translation tradition to a more student-centered, communicative conceptualization.

As educational institutions in Vietnam have been embracing new course books that are more communicative for their various ELT programs, a critical evaluation of these teaching materials is highly beneficial for both accountability and development purposes. This paper reports the evaluation of the communicative tasks of a new coursebook at the University of Transport and Communications (UTC). Thereby giving recommendations to continue to improve the quality of books for teaching and learning.

Copyright (C) 2021 The Author(s): This is an open-access article distributed under the terms of the Creative Commons Attribution 4.0 International License (CC BY-NC 4.0) which permits unrestricted use, distribution, and reproduction in any medium for noncommercial use provided the original author and source are credited. 


\section{Research Problem Context}

UTC is a typical university of science and engineering. English both general and for specific purposes are compulsory subjects for all students but, in such a setting, has only a marginal role. A UTC student is to complete at least two courses of English, depending on the student's major and his or her score in a TOEIC-based placement test at the beginning of each school year. If a student does not attend the placement test, it is assumed that (s)he is at the lowest level of English proficiency and thus has to do all the four courses, namely A1, A2, B1 and English for Specific Purposes (ESP). All students have to achieve the B1 level based on the Common European Framework of Reference for Languages (CEFR) as a requirement for their graduation as well as for enrolling in ESP courses.

As for coursebooks, A1 and A2 students learn with Straightforward Beginner - $2^{\text {nd }}$ Editions [1] and Straightforward Elementary $-2^{\text {nd }}$ Editions [2] respectively. As for B1 classes, Complete PET [3] is the main teaching material. For all the courses, students are assessed in an exam through all the four language skills, i.e. reading, writing, listening and speaking. As such, these programs are aimed at helping students to develop a well-rounded language proficiency. Only on passing the B1 test are students eligible to enroll in an ESP course of their major. Coursebooks for these programs are compiled from different resources and mostly focus on reading, grammar, and translation.

\section{Rationale}

Materials evaluation provides valuable information to determine to what extent a program "works" and facilitate the whole process of curriculum development. A micro-evaluation is characterized by a narrow focus on some specific aspect of the curriculum of the administration of the program [4]. In other words, a micro-evaluation of teaching materials provides the information to determine whether a particular task is effective and/or efficient.

The Straightforward series has been used at UTC since the first semester of the 2019-2020 academic years. Since then, there have been no formal evaluations of the coursebooks in terms of their effectiveness, efficiency, and suitability in the UTC context. The first book of the series, i.e. Straightforward Beginner $-2^{\text {nd }}$ Edition, was of particular interest because it was the required coursebook of most classes at the time this study was conducted.

\section{LITERATURE REVIEW}

\section{Materials evaluation}

Over the last few decades, there has been a strong surge of interest in evaluation in language teaching. This change reflected the more attention applied linguists have been paying to mainstream educational theory and a growing need for large-scale evaluations of funded programs. There are two broad types of evaluation in language teaching, each of which has its own goals, roles and methods.

Macro-evaluation refers to the kind of evaluation that seeks to determine (1) whether a particular program is effective and efficient in meeting its goals and (2) in what ways the program can be improved [4]. These two primary focuses of macro-evaluations are also known as "accountability evaluation" and "development evaluation" [5]. A macroevaluation requires data collected from various sources, including administrative and curriculum matters.

Micro-evaluation is the type of evaluation characterized by a concentration on a specific aspect of the curriculum or the administration of the program [4]. Theoretically, any aspect of the language teaching program can be the focus of a micro-evaluation. In the case of materials, educators may need to evaluate the effectiveness and/or efficiency of a particular task or a new teaching material. While macro-evaluations are obviously needed for the evaluation of a program, micro-evaluations typically look at the effectiveness and/or efficiency of a specific aspect of that program. From the perspective of the language teacher, micro-evaluations are more feasible and applicable than macro-evaluations [4]. It is this type of evaluation that was conducted in the present study.

Micro-evaluations can be carried out before or after a language teaching program. Before-program evaluations are quite common and are conducted to choose materials that will be suitable for a particular group of learners or to identify possible aspects of the material where adaptation is necessary. Data can be collected using established questionnaires, checklists and guides [6, 7, 8]. After-program evaluations are, however, much less common, perhaps because teachers see no need for such a systematic and principled evaluation of a material whose effectiveness and efficiency they can easily "feel" through their everyday teaching experience. Another reason could be the sheer amount of work involved in the process, which makes it a daunting task for the regular teacher [4]. Having said that, microevaluations focussing on particular tasks are highly encouraged since they allow teachers to adopt a "reflective approach" to their teaching [9]. There are three steps in conducting a micro-evaluation, be it before- or after-program: 


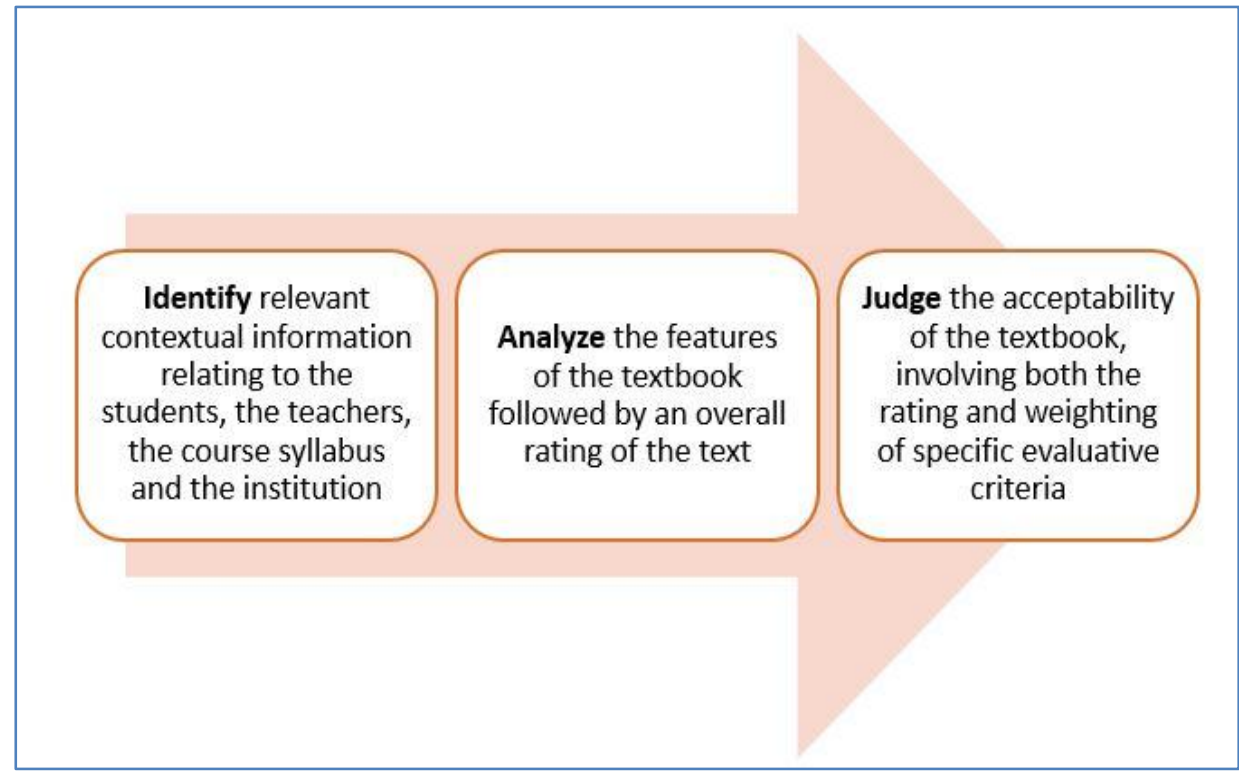

Fig-1: Steps in conducting a material evaluation (Skierso, 1991 [10], as cited in Ellis, 1998[4])

When conducting a task evaluation, there are seven aspects which the teacher-evaluator has to consider:

\begin{tabular}{|c|c|}
\hline Dimensions & Key questions \\
\hline $\begin{array}{ll}\text { Approach } \\
\text { 1. } & \text { Objective model } \\
\text { 2. } & \text { Responsive model } \\
\end{array}$ & $\begin{array}{l}\text { Is the approach to be one evaluating the task in terms of its objectives or is } \\
\text { it to be one of developing an understanding of how the task works for } \\
\text { language learning. Or both? }\end{array}$ \\
\hline $\begin{array}{l}\text { Purpose } \\
\text { 1. Accountability } \\
\text { 2. Development } \\
\text { (a) Curriculum improvement } \\
\text { (b) Teacher development }\end{array}$ & $\begin{array}{l}\text { Is the evaluation directed at determining whether the task "works" or is it } \\
\text { directed at improving the task for future use or encouraging teachers to } \\
\text { reflect on the value and use of this kind of task? }\end{array}$ \\
\hline $\begin{aligned} \text { Focus } & \\
\text { 1. } & \text { Effectiveness } \\
\text { 2. } & \text { Efficiency }\end{aligned}$ & $\begin{array}{l}\text { Is the focus of the evaluation on the effectiveness of the efficiency of the } \\
\text { task }\end{array}$ \\
\hline $\begin{aligned} \text { Scope } & \\
\text { 1. } & \text { Internal } \\
\text { 2. } & \text { External }\end{aligned}$ & $\begin{array}{l}\text { Will the evaluation of the task be in terms of its stated objectives or will it } \\
\text { consider the appropriateness of the objectives themselves? }\end{array}$ \\
\hline $\begin{array}{l}\text { Evaluator } \\
\begin{array}{ll}\text { 1. } & \text { Insiders } \\
\text { 2. } & \text { 2. Outsiders }\end{array}\end{array}$ & $\begin{array}{l}\text { Who will evaluate the task? } \\
\text { What bias do the chosen evaluators have? }\end{array}$ \\
\hline $\begin{array}{cl}\text { Timing } & \\
\text { 1. } & \text { Formative } \\
\text { 2. } & \text { Summative } \\
\end{array}$ & $\begin{array}{l}\text { Will the evaluation of the task take place as it is being used in the classroom } \\
\text { or on its completion? }\end{array}$ \\
\hline $\begin{aligned} & \text { Type of information } \\
& \text { 1. } \text { Test scores } \\
& \text { 2. } \text { Documentary } \\
& \text { 3. } \text { Self-report } \\
& \text { 4. } \text { Observation }\end{aligned}$ & $\begin{array}{l}\text { What kinds of information will be used to evaluate the task? } \\
\text { How will the information be collected? }\end{array}$ \\
\hline
\end{tabular}

Fig-2: A checklist of questions for evaluating a task [4]

\section{Task evaluation}

A task is defined as an amount of "classroom work that involves learners in comprehending, manipulating, producing or interacting in the target language while their attention is focused on mobilizing their grammatical knowledge in order to express meaning" [11]. There are four important features of a task: (1) it involves an activity of some kind, (2) it has a specific outcome, (3) it may require language comprehension or language production or both, and (4) it requires learners to focus their attention principally on meaning rather than on form [4]. 
There are five steps in the process of evaluating a task, which is visualized by Ellis [4] as follows:

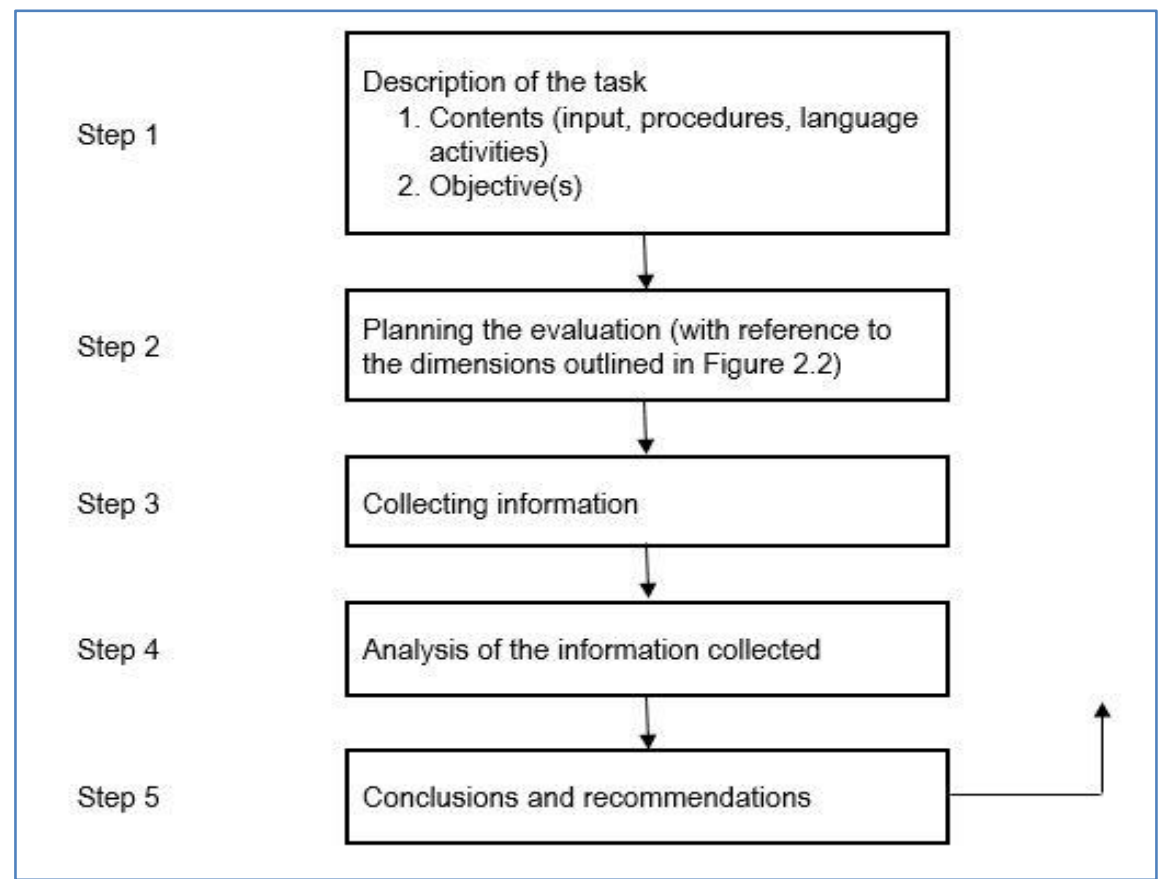

Fig-3: Steps in conducting an evaluation of a task [4]

\section{DESCRIPTION OF THE COMMUNICATIVE TASKS}

\section{Selection of the tasks}

The Straightforward $-2^{\text {nd }}$ Edition series is designed for adult and young adult learners of English with six levels from Beginner up to Advanced. Each coursebook of the series consists of 12 units, which in turn has 4 lessons (A, B, C and D). The series is claimed to boast a transparent structure, pragmatic methodology and varied contents. The current evaluation focused on the first level of the series, i.e. Straightforward Beginner.

In order to conduct the evaluation of the coursebook in interest, Lesson 11A of Unit 11 (pp. 96-97) was chosen to provide the tasks for evaluation. The reason for selecting this lesson was its representativeness of the typical tasks designed in the coursebook. Moreover, as the lesson was scheduled near the end of the course, it was hoped that by the time it was taught, the students would have been familiar enough with the coursebook and thus could provide reliable evaluation.

\section{Descriptions of the tasks}

The selected lesson consisted of 5 parts: VOCABULARY (action verbs), READING, and GRAMMAR (can/can't), PRONUNCIATION (can/can't) and SPEAKING.

All the tasks presented in each part of the lesson were described by means of Littlejohn's [12] schedule for analyzing tasks:

\begin{tabular}{|c|c|c|c|c|c|c|c|c|c|c|c|c|c|}
\hline \multirow{2}{*}{$\begin{array}{l}\text { Task analysis sheet - Lesson 11A } \\
\text { Task number }\end{array}$} & \multicolumn{2}{|c|}{ VOCAB. } & \multicolumn{4}{|c|}{ READING } & \multicolumn{2}{|c|}{ GRAM. } & \multicolumn{2}{|c|}{ PRON. } & \multicolumn{3}{|c|}{ SPEAK. } \\
\hline & 1 & 2 & 1 & 2 & 3 & 4 & 1 & 2 & 1 & 2 & 1 & 2 & 3 \\
\hline \multicolumn{14}{|c|}{ I. WHAT IS THE LEARNER EXPECTED TO DO? } \\
\hline \multicolumn{14}{|l|}{ A. TURN TAKE } \\
\hline Initiate & & & $\mathrm{x}$ & & & $\mathrm{x}$ & & & & & & & \\
\hline Respond & $\mathrm{x}$ & $\mathrm{x}$ & & $\mathrm{x}$ & $\mathrm{x}$ & & $\mathrm{x}$ & $\mathrm{x}$ & & $\mathrm{x}$ & $\mathrm{x}$ & & $\mathrm{X}$ \\
\hline Not required & & & & & & & & & $\mathrm{x}$ & & & $\mathrm{x}$ & \\
\hline \multicolumn{14}{|l|}{ B. FOCUS on } \\
\hline Language system (rules or form) & & & & & & & $\mathrm{x}$ & $\mathrm{x}$ & & & & & \\
\hline Meaning & & $\mathrm{x}$ & $\mathrm{x}$ & $\mathrm{X}$ & $\mathrm{x}$ & $\mathrm{x}$ & & & & & $\mathrm{x}$ & $\mathrm{x}$ & $\mathrm{x}$ \\
\hline Meaning/system/form relationship & $\mathrm{X}$ & & & & & & & & X & $\mathrm{X}$ & & & \\
\hline
\end{tabular}




\begin{tabular}{|c|c|c|c|c|c|c|c|c|c|c|c|c|c|}
\hline \multicolumn{14}{|l|}{ C. MENTAL OPERATION } \\
\hline Analyze language forms & & & & & & & $\mathrm{x}$ & $\mathrm{x}$ & & & & & \\
\hline Attend to example/explanation & & & & & & & & & $\mathrm{x}$ & & & $\mathrm{x}$ & \\
\hline Categorize selected information & & & & & & & & & & & $\mathrm{x}$ & & \\
\hline $\begin{array}{l}\text { Decode semantic/propositional } \\
\text { meaning }\end{array}$ & & & $\mathrm{x}$ & & $\mathrm{x}$ & & & & & & & & \\
\hline Formulate terms into larger units & & & & & & $\mathrm{x}$ & & & & & & & \\
\hline Repeat identically & & & & & & & & & & $\mathrm{x}$ & & & \\
\hline Repeat with substitution & & & & & & & & & & & & & $\mathrm{x}$ \\
\hline Retrieve from STM & & $\mathrm{x}$ & & & & & & & & & & & \\
\hline Select information & $\mathrm{x}$ & & & $\mathrm{x}$ & & & & & & & & & \\
\hline \multicolumn{14}{|l|}{ II. WHO WITH? } \\
\hline Learners individually simultaneously & $\mathrm{x}$ & $\mathrm{x}$ & $\mathrm{x}$ & $\mathrm{x}$ & $\mathrm{x}$ & & $\mathrm{x}$ & $\mathrm{x}$ & $\mathrm{x}$ & & $\mathrm{x}$ & $\mathrm{x}$ & \\
\hline $\begin{array}{l}\text { Learners in pairs/groups } \\
\text { simultaneously }\end{array}$ & & & & & & $\mathrm{X}$ & & & & & & & $\mathrm{x}$ \\
\hline Teacher \& learner(s), class observing & $\mathrm{x}$ & & $\mathrm{x}$ & $\mathrm{x}$ & & & & $\mathrm{x}$ & & $\mathrm{x}$ & $\mathrm{x}$ & & \\
\hline \multicolumn{14}{|l|}{ III. WITH WHAT CONTENT? } \\
\hline \multicolumn{14}{|l|}{ A. FORM } \\
\hline \multicolumn{14}{|l|}{ a. Input to learners } \\
\hline Extended discourse & & & $\mathrm{x}$ & $\mathrm{x}$ & $\mathrm{x}$ & & & & & & & & \\
\hline Graphic & $\mathrm{x}$ & $\mathrm{x}$ & & & & & & & & & & & \\
\hline Words/phrases/sentences, oral & $\mathrm{x}$ & & & & & & & $\mathrm{x}$ & $\mathrm{x}$ & $\mathrm{X}$ & & $\mathrm{x}$ & \\
\hline Words/phrases/sentences, written & & & & & & $\mathrm{x}$ & $\mathrm{x}$ & $\mathrm{x}$ & $\mathrm{x}$ & & $\mathrm{x}$ & $\mathrm{x}$ & $\mathrm{x}$ \\
\hline \multicolumn{14}{|l|}{ b. Expected output from learners } \\
\hline Words/phrases/sentences, oral & $\mathrm{x}$ & $\mathrm{x}$ & $\mathrm{x}$ & $\mathrm{x}$ & $\mathrm{x}$ & $\mathrm{x}$ & $\mathrm{x}$ & $\mathrm{x}$ & $\mathrm{x}$ & & & $\mathrm{x}$ & $\mathrm{x}$ \\
\hline Words/phrases/sentences, written & & & & & & & & & & $\mathrm{X}$ & $\mathrm{x}$ & & \\
\hline \multicolumn{14}{|l|}{ B. SOURCE } \\
\hline Materials & $\mathrm{x}$ & $\mathrm{x}$ & $\mathrm{x}$ & $\mathrm{x}$ & $\mathrm{x}$ & & $\mathrm{x}$ & $\mathrm{x}$ & $\mathrm{x}$ & $\mathrm{x}$ & $\mathrm{x}$ & $\mathrm{x}$ & $\mathrm{x}$ \\
\hline \multicolumn{14}{|l|}{ Teacher } \\
\hline Learner(s) & & & & & & $\mathrm{x}$ & & & & & & & \\
\hline \multicolumn{14}{|l|}{ C. NATURE } \\
\hline Linguistic items & $\mathrm{x}$ & $\mathrm{x}$ & & & & & $\mathrm{x}$ & $\mathrm{x}$ & & $\mathrm{x}$ & & & \\
\hline Metalinguistic comment & & & & & & & & & $\mathrm{x}$ & & & & \\
\hline Non-fiction & & & & $\mathrm{x}$ & $\mathrm{x}$ & & & & & & & & \\
\hline Fiction & & & & & & & & & & & & $\mathrm{x}$ & $\mathrm{x}$ \\
\hline Personal information & & & $\mathrm{X}$ & & & $\mathrm{x}$ & & & & & $\mathrm{x}$ & & \\
\hline
\end{tabular}

\section{Data Collection \\ Participants}

Students of different majors registered in two A1 classes using Straightforward Beginner $-2^{\text {nd }}$ Editions at UTC were invited to participate, resulting in a convenient sample of 62 participants. They ranged in age from 18 to 20 , with a mean age of 18.94 years. Male students composed $61 \%$ of the sample. The length of time spent learning English ranged from 3 years to 13 years $(M=7.84, S D=1.74)$. Most of them were from Central and Southern Vietnam $(55 \%$ and $35 \%$ respectively). Only 2 students were from Ho Chi Minh City (0.3\%), where UTC is located.

\section{Instrument}

A questionnaire was designed to investigate the participants' attitudes towards the teaching of Lesson 11A. This instrument consisted of 10 items. The first section collected demographic information, including gender, age, learning experience and hometown (Items 1, 2, 3 and 4). The second section obtained students' evaluation of the lesson. Items 5, 6 and 7 asked students to give their opinions about the interestingness, usefulness, and difficulty of all the tasks in the lesson. Items 8 and 9 were intended to elicit students' general evaluation of the lesson as a whole. Item 10 was an openended question where students could give further comments or suggestions.

\section{Procedure}

The questionnaires were delivered immediately after the students finished Lesson 11A. The students were informed that their participation was voluntary and that their responses were strictly confidential and would not affect their course results. They were allowed enough time to complete the questionnaire at their discretion. 


\section{Data AnAlysis}

\section{Interestingness, usefulness, and difficulty of the tasks}

To investigate the participants' attitudes towards the teaching of Lesson 11A, mean analyses were conducted. Mean scores of the five parts of the lesson were compared in terms of their interestingness (Item 5), usefulness (Item 6) and difficulty (Item 7) and must fall between 1 (lowest level) and 5 (highest level).

As shown in Table 5.1, the most interesting tasks in the lesson were in Reading $(M=4.22, S D=.46)$, Pronunciation $(M=3.63, S D=1.33)$ and Vocabulary $(M=3.56, S D=1.06)$. The least interesting was Grammar $(M=$ $1.99, S D=.81)$, followed by Speaking $(M=2.27, S D=.89)$.

As for usefulness, Vocabulary scored the highest of all $(M=4.11, S D=.64)$, followed by Pronunciation $(M=$ 4.03, $S D=.64)$. Reading and Grammar were moderately useful, with mean scores of 3.57 and 2.93 respectively. Speaking was the least useful tasks at $M=2.31(S D=1.15)$

As for difficulty, all the tasks seemed to be relatively easy for the participants, with mean scores of Vocabulary, Reading, Grammar and Speaking ranging from 1.32 to 1.90. Pronunciation was perceived to be the most difficult $(M=$ $2.93, S D=.98)$, although the degree of difficulty is not very high.

Table-1: Mean scores: Interestingness, usefulness, and difficulty of the group of tasks in Unit 11A

\begin{tabular}{|l|c|c|c|c|c|c|c|c|}
\hline & \multicolumn{3}{|c|}{ N } & \multicolumn{2}{c|}{ Interestingness } & \multicolumn{2}{c|}{ Usefulness } & \multicolumn{2}{c|}{ Difficulty } \\
\cline { 2 - 10 } & Valid & Missing & Mean & SD & Mean & SD & Mean & SD \\
\hline Vocabulary & 62 & 0 & 3.56 & 1.06 & 4.11 & .64 & 1.32 & .91 \\
\hline Reading & 62 & 0 & 4.22 & .46 & 3.57 & 1.28 & 1.86 & 1.54 \\
\hline Grammar & 62 & 0 & 1.99 & .81 & 2.93 & 1.77 & 1.90 & 1.04 \\
\hline Pronunciation & 62 & 0 & 3.63 & 1.33 & 4.03 & .64 & 2.93 & .98 \\
\hline Speaking & 62 & 0 & 2.27 & .89 & 2.31 & 1.15 & 1.79 & .67 \\
\hline
\end{tabular}

Table-2: Lesson 11A: Students' satisfaction and concentration

\begin{tabular}{|c|c|c|c|c|}
\hline & \multicolumn{2}{|c|}{ N } & \multirow{2}{*}{ Mean } & SD \\
\cline { 2 - 5 } & Valid & Missing & & \\
\hline Level of concentration & 62 & 0 & 4.11 & .67 \\
\hline General satisfaction & 62 & 0 & 3.96 & .70 \\
\hline
\end{tabular}

As presented in Table 2, students showed a high level of concentration during the lesson $(\mathrm{M}=4.11, \mathrm{SD}=.67)$. They were moderately satisfied with the teaching of the lesson $(\mathrm{M}=3.96, \mathrm{SD}=.70)$. As for further comments or suggestions for improvement (Item 10), most of the respondents expected to have more interesting grammar exercises. A few of them complained that the grammar tasks were too easy and thus boring. The speaking part also received negative comments for being "repetitive" and even "childish". Some of the respondents suggest that the teacher should replace these tasks with more engaging ones. Vocabulary and Reading received the most positive feedback in terms of clarity, effectiveness, and appearance. One respondent particularly liked the reading text because he "learned to appreciate people with disabilities".

\section{DISCUSSION}

The above analysis of the collected data revealed that students were generally satisfied with the lesson in investigation. More specifically, Vocabulary and Reading tasks were the most successful sections of the lesson. Pronunciation tasks were also perceived to be useful and interesting although most students felt that they were rather difficult. Grammar and Speaking tasks were the most problematic in the lesson. Although these tasks were not considered difficult by the students, they were perceived to be neither interesting nor useful. Unsurprisingly, comments and suggestions largely focused on the improvement of these tasks.

As shown in the above task analysis sheet, the two Grammar tasks were all about forms and rules (focusing on "Language system") where students were passively engaged in the learning process ("Respond" turn-take). The only mental operation process was "analyze language forms". These factors altogether might have caused boredom from the students' part, as evidenced in their comments and suggestions for improvement.

On the other hand, the "failure" of the Speaking tasks seemed to be about the repetitiveness and lack of creativity of the tasks. For adult learners, the presented tasks might have been too simplistic, making them mundane and 
not challenging enough. Another possible explanation is about the "learning culture" of Vietnamese students. It has been well documented that the Vietnamese language learner is often shy when it comes to activities that require active participation like speaking [13]. The problem was perhaps further amplified in the context of UTC, where all students were non-English majors and mostly came from underdeveloped areas.

\section{CONCLUSiOnS}

Through the above descriptions, analyses and discussions, it can be concluded that Lesson 11A in particular and Straightforward Beginner - 2nd Edition in general is suitable for use at UTC. The lesson is highly interesting and useful when used for teaching vocabulary and reading. However, grammar presentations and practices do not seem to be suitable for these adult learners. Speaking tasks do not seem to match the learners' expectations of the coursebook. As for pronunciation tasks, the coursebook provide interesting activities although it might be necessary that teachers give additional guidance and encouragement to support learners.

\section{REFERENCES}

1. Clandfield, L. (2013). Straightforward Beginner Student's Book with Practice Online access. Oxford: Macmillan.

2. Clandfield, L. (2012). Straightforward Elementary Student's Book with Practice Online access. Oxford: Macmillan.

3. Heyderman, E., \& May, P. (2010). Complete PET Students'Book with answer with CD-ROM. Cambridge: Cambridge University Press.

4. Ellis, R. (1998). The evaluation of communicative tasks. In B. Tomlinson (Ed.), Materials development in language teaching (pp. 217-238). Cambridge: Cambridge University Press.

5. Weir, C., \& Roberts, J. (1994). Evaluation in ELT. Oxford: Blackwell.

6. Cunningsworth, A. (1984). Evaluating and Selecting ELT Materials. London: Heinemann.

7. Breen, M., \& Candlin, C. (1987). Which materials? A consumer's and designer's guide. In L. Sheldon (Ed.), ELT Textbooks and Materials: Problems in Evaluation and Development (pp. 126-140). London: Modern English Publications.

8. McDonough, J., \& Shaw, C. (1993). Materials and Methods in ELT. Oxford: Blackwell.

9. Richards, J., \& Lockhart, C. (1994). Reflective Teaching in Second Language Classrooms. Cambridge: Cambridge University Press.

10. Skierso, A. (1991). Textbook selection and evaluation. Teaching English as a second or foreign language, 2, 432453.

11. Nunan, D. (1999). Second Language Teaching and Learning. Boston: Heinle \& Heinle.

12. Littlejohn, A. (1998). The analysis of language teaching materials: Inside the Trojan Horse. In B. Tomlinson (Ed.), Materials development in language teaching (pp. 190-216). Cambridge: Cambridge University Press.

13. Littlewood, W. (2000). Do Asian students really want to listen and obey?. ELT Journal, 54(1), 31-36.

CITATION: Nguyen Kim Vu Bao (2021). Communicative Tasks in a Beginner Coursebook: An Evaluation at the University of Transport and Communications. South Asian Res J Human Soc Sci, 3(2): 56-62. 